\title{
Public Health, Ethical Vegetarianism, and the Harms of the Animal Food Industry
}

\author{
William 0 Stephens* \\ Department of Philosophy, Creighton University, Omaha, USA
}

*Corresponding author: William O Stephens, Department of Philosophy, Creighton

University, USA.

Received Date: June 28, 2019

Published Date: July 02, 2019

\begin{abstract}
In the West, the history of philosophical vegetarianism began in ancient Greece and Rome, not the 1970s. Yet as the global human population has grown, so has the world's population of domesticated livestock. The expanding industrialization of the animal food sector is guilty of various serious environmental and societal harms, including climate change and public health threats. The meat industrial complex, perpetuated by the ideology of carnism, is too inefficient, too damaging, and too costly to sustainably feed a growing human population. The virtuous choice is to replace meat, eggs, and dairy products with plant-based foods.
\end{abstract}

Keywords: Vegetarianism; CAFO; Meat industrial complex; Carnism; GHG; 4Ns

\section{Review}

Food is and always has been a serious issue for public health, agriculture, the environment, and ethics. First, a brief sketch of the history of the philosophical vegetarianism is offered. This overview will allow several contemporary concerns about agricultural systems, resultant environmental harms, threats to public health, food insecurity, and dietary choices to be historically contextualized and interrelated. The conceptual map presented more or less chronologically here does not pretend to be comprehensive. But despite its necessary incompleteness and unavoidable selectivity the hope is that it may prove of modest use to inform food-secure consumers who enjoy a range of healthy food options, desire to safeguard public health, support sustainable agriculture, maintain ecological integrity, and work for climate stability.

In the Western hemisphere, the idea of philosophical vegetarianism has a history of nearly 1,000 years in ancient Greece. The belief that it is wrong to eat animals was propounded by many of the most eminent ancient philosophers: Pythagoras, Empedocles, Theophrastus, who succeeded Aristotle as head of the Lyceum, Plutarch, Plotinus, and Porphyry. Porphyry, a prolific polymath, compiled a wide range of arguments against vegetarianism, critiqued them in detail, and defended at length his own Plotinian arguments for vegetarianism, in his work De

Abstinentia ab Esu Animalium [1]. In ancient Rome, Pythagoras' arguments for philosophical vegetarianism won over the Stoic philosopher, statesman, orator, and dramatist Seneca, who reported improved health and vigor as benefits of abstaining from meat. Seneca believed that Stoic philosophy, which grounds the virtues of wisdom, justice, and temperance in pursuit of living in agreement with nature, dictates simple, simply prepared, frugal meals of foods that are close at hand. Thus, Seneca advocated moderate, unfussy eating and condemned foods requiring great labor, expense, or trouble. Seafood, imported foods, meat from hunted animals, and exotic mushrooms he criticized as decadent luxuries.

The respected Roman Stoic teacher Musonius Rufus also emphasized the virtues of simplicity and frugality in eating. He argued that the proper diet consists of the least expensive and most readily available foods: raw fruits in season, raw and cooked vegetables, milk, cheese, honeycombs, and cooked grains. Like Seneca, Musonius rejected meat as too crude for human beings and more suitable for wild animals. Musonius concluded that responsible people favor what is easy to obtain over what is difficult, what involves no trouble over what does, and what is available over what isn't, because doing so promotes self-control and virtue of character. For him, these values called for a lacto-vegetarian diet 
[2]. Consequently, contemporary philosophical vegetarianism, a movement born in the 1970s [3], is not a new idea, but rather a very old one [4].

In the ancient world the human population of the planet was far, far smaller than it is today while the diversity of species of plants and animals was far greater. Humans and their ancestors have had negative impacts on species biodiversity for nearly two million years. Extinction rates have accelerated since the origins of agriculture. Today entire ecosystems are in peril due to the relentless growth of the human population [5]. One of the worst culprits of environmental destruction has been the cattle industry. In a study interweaving anthropology, sociology, economics, and ecology, one researcher traced the history of bovine husbandry from ancient Sumer to the Dickensian disassembly lines of Chicago's stockyards of the 1830s [6]. Rifkin presented a scathing indictment of the cattle culture that has come to shape and warp our world. He debunked the myth of the cowboy to expose the international intrigue, political giveaways, and sheer avarice that transformed the great American frontier into a huge cattle breeding ground. Intensive, largescale industrial methods were first used to produce chickens in 1923 [7]. The economic advantages of the growing meat industrial complex come at the cost of serious harms to public health and the stability of ecosystems. Concentrated animal feeding operations (CAFOs) are where increasing amounts of the world's meat, milk, eggs, and seafood are produced. The rise of the global CAFO industry has become one of the most pressing issues of our time. The routine practice of cramming thousands of animals into filthy conditions dependent on antibiotic medicines and steady streams of subsidized industrial feeds raises serious public health concerns. These include food poisoning, outbreaks of avian flu viruses, outbreaks of swine flu, including H1N1, and bovine spongiform encephalopathy (BSE). Moreover, CAFOs flagrantly violate reasonable standards for the ethical treatment of the animals and are ecologically unsustainable [8].

Today the number of domesticated livestock animals is considerably greater than it has ever been in human history. The manifold harms of the meat (and dairy) industrial complex, were recognized and described several decades ago by environmentalists, advocates of animal welfare, and researchers on food policy and public health. A 1994 study canvassing these sources reconstructed five different sets of considerations which separately and collectively recommend vegetarianism. These five arguments are: (a) the argument from distributive justice, according to which the global system of meat production so inefficiently distributes agricultural resources that in effect it unfairly deprives poor people of adequate food while providing meat as a dietary luxury to the wealthy; (b) the argument from environmental harm, according to which the world livestock industry causes significant, manifold ecological damage; (c) the feminist argument from sexual politics, according to which meat-eating cultures and societal oppression of women are intimately linked, and so feminism and vegetarianism must both be embraced to transform our patriarchal culture into an egalitarian one; (d) the argument from moral consideration for animals, according to which, both for consequentialist (utilitarian) and deontological (rights-based) reasons, raising and slaughtering animals for food when plant-based diets are readily available is immoral, so we ought to boycott meat; and (e) the prudential argument from health, according to which consuming meat, eggs, and dairy products significantly increases the risk of contracting serious diseases and lowers life expectancy. These illnesses include trichinosis, salmonella, mercury poisoning, clostridium perfringens gastroenteritis, heart disease, atherosclerosis, high cholesterol, obesity, stroke, peptic ulcers, osteoporosis, kidney disease, and various cancers. Those who suffer from angina and other cardiac diseases, rheumatoid arthritis, kidney stones, diverticulosis, gall bladder disease, peptic ulcers, diabetes, asthma, and hypertension have been shown to benefit by switching to a vegetarian diet. This cumulative case establishes that vegetarianism is, in at least five different respects, a virtuous dietary commitment. Therefore, working toward a meatless diet is a worthy endeavor for a person who values compassion, humility, and integrity [9].

Subsequent research has provided additional support for these five arguments. For example, a study published in early 2009 reported that the livestock sector accounts for $80 \%$ of total anthropogenic land use and $18 \%$ of greenhouse gas (GHG) emissions. New insights in the adverse health effects of beef and pork have led to a revision of meat consumption recommendations. By using an integrated assessment model, this study found a global food transition to less meat, or even a complete switch to plantbased protein food, to have a dramatic effect on land use. Huge areas of cropland could be abandoned to regrow vegetation, resulting in a large carbon uptake. Methane and nitrous oxide emissions would also be reduced substantially. Dietary changes could therefore not only create considerable benefits for human health and global land use but can also help future climate change mitigation policies [10]. Another study published in late 2009 argued that the life cycle and supply chain of domesticated animals raised for food have been vastly underestimated as a source of greenhouse gases (GHGs), and actually account for at least half of all anthropogenic GHGs. This study similarly judged that replacing livestock products with better (plant-based) alternatives would be the best strategy for reversing climate change [11].

Social and cultural resistance to information about the many serious harms of meat production and consumption invited psychological study. The invisible, violent, entrenched belief system underlying the behavior of eating animals without thinking about what we are doing and why was termed carnism in 2010. This violent ideology, it was argued, comprises a vast mythology surrounding meat supported by every single institution in society, from medicine to education. The mythology sustaining carnism invokes three fundamental justifications, that eating meat is normal, natural, and necessary [12].

In 2012 other research connected the meat-heavy dietary habits of affluent nations, continuing population growth, global climate change, water shortages, soil erosion, and the conversion 
of food into fuel for cars to increasing food insecurity [13]. A more fine-grained comparison of the GHG emissions in 61 different categories of food with information on the diet of different groups of the population (omnivorous, vegetarian, and vegan) was made to ascertain the embodied GHG emissions in different dietary scenarios in the UK. The study found that potential GHG savings of $22 \%$ and $26 \%$ can be made by changing from the current UKaverage diet to a vegetarian or vegan diet, respectively. This is equivalent to a $50 \%$ reduction in exhaust pipe emissions from the entire UK passenger car fleet in 2009. This study concluded that realistic choices about diet can make substantial differences to embodied GHG emissions [14].

A thorough economic analysis of the American animal food industry was presented in 2013. According to this study, taxpayers pay $\$ 38$ billion each year to subsidize meat, fish, eggs, and dairy as a form of corporate welfare. Since the majority of crops grown in the US are used as animal feed, America's enormous farm subsidy program turns the system upside down. The government handouts encourage farmers to grow more feed crops even as prices decline. This subsidy policy consistently puts small farmers out of business and damages rural communities domestically and abroad. Though conventional wisdom ascribes decisions to buy animal foods to factors like taste, dietary beliefs, and cultural traditions, the reality is that price plays a huge role in our eating choices as well. The animal food sector wields its considerable economic clout to exert enormous influence over lawmaking at both the state and federal levels. Compared to plant protein, raising animal protein takes up to one hundred times more water, eleven times more fossil fuels, and five times more land. More than any other microeconomic system in the US, the meat industrial complex aggressively shifts the staggering costs of producing its products onto American taxpayers and consumers. The total production costs imposed on society not paid by animal food producers are $\$ 414$ billion. These costs are exacted in higher taxes, health insurance premiums, and decreases in the value of homes and natural resources impacted by CAFOs. For every dollar in retail sales of meat, fish, eggs, or dairy, the animal food industry imposes $\$ 1.70$ of external costs on society. The influence of corporate lobbyists over lawmakers has risen dramatically in the last half century. In the past few decades, the animal food industry has convinced lawmakers to protect animal food production and weaken consumer protections. How much meat and dairy Americans buy and consume is often perceived as demand driven, spurred by consumer preferences and disposable income. Yet actually American consumption of animal foods is heavily supply driven and propelled by producer behavior. This study concludes that the microeconomic system that produces meat and dairy is typified by overconsumption, huge inefficiencies, and massive hidden costs. As a result, the broken system of the meat industrial complex damages Americans' health, hurts the environment, treats animals cruelly, and generates significant, measurable, financial losses [15].

The ecological effects of dietary changes in the European Union (EU) was the focus of a 2014 study. By using biophysical models and methods, this study examined the large-scale consequences in the EU of replacing $20-50 \%$ of animal-derived foods with plant-based foods on a dietary energy basis, assuming corresponding changes in production. The study found that halving the consumption of meat, dairy products, and eggs in the EU would achieve a $40 \%$ reduction in nitrogen emissions, a $25-40 \%$ reduction in GHG emissions, and $23 \%$ per capita less use of cropland for food production. The dietary changes would also lower health risks. The nitrogen use efficiency of the food system would increase from the current $18 \%$ to between $41 \%$ and $47 \%$, depending on choices made regarding land use. As agriculture is the major source of nitrogen pollution, this is expected to result in a significant improvement in both air and water quality in the EU. The resulting $40 \%$ reduction in the intake of saturated fat would lead to a reduction in cardiovascular mortality [16].

On Joy's account, carnism appeals to the three Ns of justification, that meat eating is normal, natural, and necessary. To these three common rationalizations a fourth $\mathrm{N}$ was added, namely, that eating meat is nice. The results of six studies on the 4Ns were published in 2015. Studies $1 \mathrm{a}$ and $1 \mathrm{~b}$ showed that the $4 \mathrm{~N}$ classification captures the vast majority (83\%-91\%) of justifications people naturally offer in defense of eating meat. In Study 2, individuals who endorsed the $4 \mathrm{Ns}$ tended also to objectify (dementalize) animals and included fewer animals in their circle or moral concern, and this was true independent of social dominance orientation. Studies 3-5 showed that individuals who endorsed the $4 \mathrm{Ns}$ tend not to be motivated by ethical concerns when making food choices, are less involved in animal-welfare advocacy, less driven to restrict animal products from their diet, less proud of their animal-product decisions, tend to endorse speciesist attitudes, tend to consume meat and animal products more frequently, and are strongly committed to eating meat. Furthermore, omnivores who strongly endorsed the $4 \mathrm{Ns}$ tended to experience less guilt about their animal-product decisions, highlighting the guilt-alleviating function of the 4Ns [17].

The case for shifting dietary patterns for the environmental benefit of mitigating climate change has received growing interest from policy makers, academics, and society. Many researchers have emphasized the need for changes to food consumption in order to achieve the required GHG reductions. So far, food consumption has not been anchored in climate change policy to the same extent as energy production and usage, nor has it been considered within the context of achieving GHG targets to a level where tangible outputs are available. To address those issues a recent study performs a simple analysis that considers the extent to which one food exchange could contribute to achieving GHG reduction targets in the US. Using the targeted reduction for 2020 as a reference and applying published Life Cycle Assessment data on GHG emissions to beans and beef consumed in the US, this study calculates the difference in GHGs resulting from replacing beef with beans in terms of both calories and protein. The results show that substituting beans for beef could achieve approximately $46 \%$ to $74 \%$ reductions needed to meet the $2020 \mathrm{GHG}$ target for the US. In turn, this dietary shift would free up $42 \%$ of US cropland. While not 
currently recognized as a climate change policy option, the "beans for beef" scenario offers significant climate change mitigation and other environmental benefits, illustrating the high potential of animal to plant food shifts [18]. Increasing investments in and curiosity about meat alternatives seems to be a promising sign. Fake meat has many advantages over carnal meat [19].

\section{Conclusion}

All things considered, the industrial complex using CAFOs to produce meat, eggs, and dairy abuses animals, worsens climate change, destabilizes ecosystems, wastes energy, water, and land, pollutes air and water, and is a very costly, unjust system. In order to achieve food security and food sovereignty, mitigate climate change, slow the loss of biodiversity, stabilize ecosystems, feed the world's growing population, safeguard public health, and promote food justice, affluent nations must replace the very wasteful and destructive animal food industry with sustainable, egalitarian plantbased food systems. This will likely require broader educational outreach, grassroots movements, community partnerships, aggressive environmental policies, and visionary political reforms. It will also require individuals who actively practice the ancient virtues of wisdom, simplicity, frugality, temperance, and justice.

\section{Acknowledgment}

None.

\section{Conflict of Interest}

No conflict of interest.

\section{References}

1. Porphyry (2000) On Abstinence from Killing Animals (translated by Clark G). Cornell University Press, Ithaca, USA.

2. Stephens WO (2018) Stoicism and Food. In: Kaplan D (ed.) Encyclopedia of Food and Agricultural Ethics. Springer, Dordrecht, Netherlands.

3. Singer P (1975) Animal Liberation: A New Ethics for Our Treatment of Animals. HarperCollins, USA.
4. Dombrowski, DA (1984) The Philosophy of Vegetarianism. The University of Massachusetts Press, Amherst, Massachusetts, USA, p. 2.

5. McKee JK (2005) Sparing Nature: The Conflict between Human Population Growth and Earth's Biodiversity. Rutgers University Press, New Brunswick, USA.

6. Rifkin, J (1992) Beyond Beef: The Rise and Fall of the Cattle Culture. Dutton, USA.

7. Foer JS (2009) Eating Animals. Little, Brown and Company, New York, New York, USA, pp. 104-105.

8. Imhoff D (2010) The CAFO Reader: The Tragedy of Industrial Animal Factories. University of California Press, Berkeley, California, USA.

9. Stephens WO (1994) Five Arguments for Vegetarianism. Philosophy in the Contemporary World 1(4): 25-39.

10. Stehfest E, Bouwman L, Van Vuuren DP, Den Elzen MGJ, Eickhout B, et al. (2009) Climate Benefits of Changing Diet. Climatic Change 95: 83-102.

11. Goodland R, Anhang J (2009) Livestock and Climate Change. World Watch Magazine 22(6): 10-19.

12. Joy M (2010) Why We Love Dogs, Eat Pigs, and Wear Cows. Red Wheel/ Weiser, San Francisco, California, USA, pp. 96-97.

13. Brown LR (2012) Full Planet, Empty Plates: The New Geopolitics of Food Scarcity. Earth Policy Institute, W. W. Norton and Company, New York, New York, USA.

14. Berners-Lee M, Hoolohan C, Cammack H, Hewitt CN (2012) The Relative Greenhouse Gas Impacts of Realistic Dietary Choices. Energy Policy 43: 184-190.

15. Simon, DR (2013) Meatonomics. Red Wheel/Weiser, San Francisco, California, USA

16. Westhoek H, Lesschen JP, Rood T, Wagner S, De Marco A et al. (2014) Food Choices, Health and Environment: Effects of Cutting Europe's Meat and Dairy Intake. Global Environmental Change 26: 196-205.

17. Piazza J, Ruby MB, Loughnan S, Luong M, Kulik J, Watkins HM, Seigerman M (2015) Rationalizing Meat Consumption: The 4 Ns. Appetite 91: 114128.

18. Harwatt H, Sabaté J, Eshel G, Soret S, Ripple W (2017) Substituting Beans for Beef as a Contribution toward US Climate Change Targets. Climatic Change 143: 261-270.

19. Stephens WO (2018) Fake Meat. In: Kaplan D (Ed.) Encyclopedia of Food and Agricultural Ethics. Springer, Dordrecht, Netherlands. 